\title{
Intertextuality or Story Resistance? A Deconstruction of Stories with Preschoolers: An Example of "The Little Red Riding Hood"
}

\author{
Dilek Altun ${ }^{1, *}$, Mustafa Ulusoy ${ }^{2}$ \\ ${ }^{1}$ Department of Early Childhood Education, Faculty of Education, Ahi Evran University, Turkey \\ ${ }^{2}$ Department of Primary Teaching, Faculty of Education, Gazi University, Turkey
}

Copyright $\bigcirc 2019$ by authors, all rights reserved. Authors agree that this article remains permanently open access under the terms of the Creative Commons Attribution License 4.0 International License

\begin{abstract}
Storybook reading experiences have the potential to foster children's cognitive skills in regard to sequencing a story plot, making predictions about the outcome, comprehending the story's message, and understanding cause and effect relationships. Deconstruction enables children to think critically about the story's protagonist's perspectives, themes, and messages. Thus, deconstruction can be a useful method for examining a story's elements with children and triggering them to make intertextual connections among stories. This study focuses on preschoolers' intertextual connection competencies and provides them with a novel activity. Therefore, the study focused on a well-known fairytale titled "The Little Red Riding Hood" along with two different, newer versions of the story. The present study's participants included thirty preschool children (fifteen girls and fifteen boys). The following three versions of the "Red Riding Hood" stories were read twice during the small group reading activity: "The Little Red Riding Hood," "Very Little Red Riding Hood" (written by Teresa Heapy, illustrated by Sue Heap), and "Who is Afraid of Red Riding Hood?" (written by Sara Şahinkanat, illustrated by Ayşe İnan Alican). The stories present different perspectives and contradictory messages regarding the same topic. The findings revealed that the children talked about intertextual linkage between story plots wherein they focused on the climaxes as dissimilar and similar points. The study findings show that half of the children retold their stories along the same lines as those in the previous stories. On the other hand, eleven children drew intertextual connections in their stories and combined different characters, plots, and/or settings from the three versions. Deconstruction can be a fruitful teaching method with which early childhood teachers may encourage children to assert perspectives, think critically, and make intertextual connections among stories to foster their story comprehension.
\end{abstract}

Keywords Deconstruction, Story, Preschooler,
Intertextuality, the Little Red Riding Hood

\section{Introduction}

Storybook reading is a fruitful and enjoyable early childhood activity that supports children's development and learning [1]. A plethora of research has thoroughly documented that reading and telling stories to young children foster their vocabulary development, narrative skills, print awareness, story comprehension, and understandings of print-related concepts $[2,3,4,5,6,7]$. Furthermore, storybook reading experiences have the potential to foster children's cognitive skills in regard to sequencing a story plot, making predictions about the outcome, comprehending the story's message, and understanding cause-and-effect relationships [8]. Stories also provide enriched context with which children may introduce different themes, protagonists, problems, and solutions as well as think and learn about protagonists' perspectives, feelings, beliefs, and mental states. In addition, stories present their writers' points of view and allow children to construct their own meanings from them. Children are enabled to execute both interpersonal and intrapersonal intelligence during reading activities [9]. Therefore, stories can be used as a tool to support children's critical thinking skills [10]. Sipe [11] articulated that implementing intertextual connections during story reading can be an effective way to bolster children's critical thinking skills and meaning construction obtained from stories.

\subsection{Intertextuality}

The term "intertextuality" was derived from Julia Kristeva (1969) [14], who endeavored to blend both 
Saussure's and Ferdinand's semiotics and extend the notion of the text boundaries aside from the solely written discourse. She reflected poststructuralist perspectives on the text notion and asserted that the multimodality of semiotics, such as visuals, gestures, images, mimed features, as well as aural and spatial aspects, are also kinds of texts because these devices carry messages and derive meanings from them. Kristeva additionally advocated intersubjectivity in the meaning-making process, which asserts that texts' meanings are dependent upon other texts and that intra-textual relations exist $[12,13,14]$. A reader's prior reading experiences regarding content, visuals, writing style, message, and context may potentially affect the next reading comprehension process. The reader transforms prior experiences and knowledge through the following meaning-making process, and thus there exists interdependency between texts (intertextual connections). Hartman [15] examined eight competent readers' intertextual connections while reading five texts. He determined the readers made the following two main intertextual links between the passages: (a) socio-cultural and historical linkages, and (b) connections among incidents, thoughts, and characters. Research has revealed that primary-grade children make intertextual connections among different texts, genres, and subjects (thematic connections) $[16,17,18,11,19]$. Furthermore, first-grade children are capable of making linkages among story elements such as characters, plots, scenes, themes, and phrases in their story-based discourses [20].

The majority of intertextuality studies have been conducted with school-aged children. However, studies have provided evidence that children make connections between read-aloud stories and their play [21]. In addition, young children are capable of establishing intertextual linkages between stories and their personal experiences [22, $23,24]$. It is also essential that emergent-reader children assemble their daily experiences, prior knowledge, and backgrounds during shared book reading practices to facilitate the meaning-making process [25]. However, only a limited number of studies have investigated the emergence of intertextuality in young children [11, 23], and thus this study implements the deconstruction method to expand educators' knowledge of young children's intertextuality connections during storybook reading.

\subsection{Deconstruction}

The term "deconstruction" comprises two parts- "de" (reversal or removal) and "construct" (to put together parts) - and refers to the process of taking apart concepts and meanings [26, p. 268]. The theoretical background behind deconstruction is based on Jacques Derrida's study and poststructuralist language theories. According to Derrida [27], meanings are constructed through the changing relations between a binary opposition. For example, the meaning of gender is established through the binary opposition of a male and a female [26, 27]. The aim of the deconstruction is to clarify the relations of power between the two dichotomies and demonstrate their links rather than their oppositions, hence creating as many new meanings as possible $[26,27]$. As a teaching technique, Mac Naugton and William [26] suggested helping children examine the stories they read and encouraging them to think of alternative possibilities. Deconstruction enables children to think critically about a story's themes and messages as well as a protagonist's perspectives. Thus, deconstruction can be a useful method for examining a story's elements with children and triggering them to make intertextual connections among different versions of the same story.

This study focuses on preschoolers' intertextual connection competencies and provides them with a novel activity. Therefore, the study focused on a well-known fairytale titled "The Little Red Riding Hood" along with two different, newer versions of the story. The present study aimed to deconstruct these stories with preschoolers by helping them engage in a critical examination of the stories' messages and protagonists' points of view.

\section{Materials and Methods}

A qualitative case study method was used to examine preschoolers' story deconstruction abilities. The present study's participants included thirty preschool children (fifteen girls and fifteen boys) recruited from three classes in two public preschools in Kırşehir, Turkey. After receiving official permission from both ethics commissions and the National Ministry of Education, informed consent forms were sent to parents via children's preschool teachers. The children were selected using a purposeful sampling method regarding gender and age. Previous studies provide evidence that children's story comprehension and production can be differentiated according to their gender and age groups [38,39]. Older age groups in addition to girls in general tended to exhibit more favorable performances. Therefore, the age group was standardized as children aged five years and the distribution of the children's genders was equalized. The children's mean age was 63.55 months $(\mathrm{SD}=2.45)$, and all were preliterate, monolingual Turkish children. The participating children were typically developed based on their parents' and the three classroom teachers' reports.

The following three versions of the "Red Riding Hood" stories were read twice during the small group reading activity: "The Little Red Riding Hood," (adapted by Susanna Davidson, illustrated by Mike Gordon) "Very Little Red Riding Hood" (written by Teresa Heapy, illustrated by Sue Heap), and "Who is Afraid of Red Riding Hood?" (written by Sara Şahinkanat, illustrated by Ayşe İnan Alican). The stories depict different perspectives and contradictory messages regarding the same topic. First, the original version, "The Little Red Riding Hood," was read to refresh the children's memories and determine their familiarity with the story; all children were familiar with 
the original version. In order to eliminate the order of book effects, the storybooks counterbalanced into two sub-groups. During the second book reading session, half the children were read "Very Little Red Riding Hood," while the other half were read "Who is Afraid of Red Riding Hood?" as a second story. Figure 1 presents the storybook reading process. This study's first author, a faculty member at a state university and a children's literature lecturer, read the three stories to the participating children. Storybook reading sessions were conducted as small groups with three or four children each. Storybook reading processes were standardized among the three storybooks and the groups. All reading sessions were held in rooms in the schools separate from their own classroom, and the researcher read aloud each book twice using appropriate prosody.

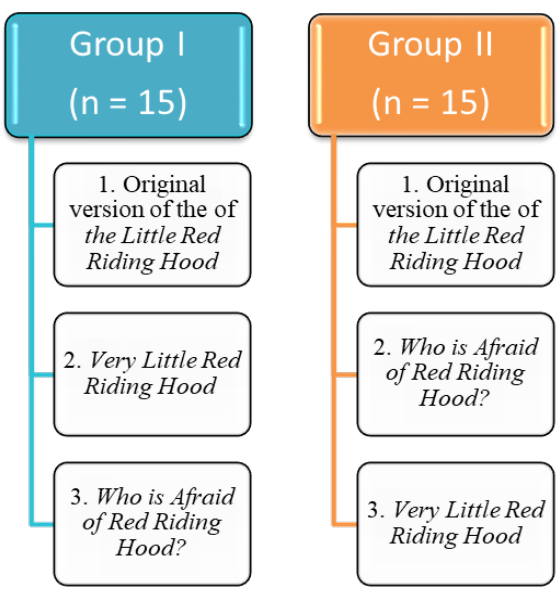

Figure 1. The Storybook Reading Process

First, the original version, "The Little Red Riding Hood," was read to refresh the children's memories and determine their familiarity with the story; all children were familiar with the original version. In order to eliminate the order of book effects, the storybooks counterbalanced into two sub-groups. During the second book reading session, half the children were read "Very Little Red Riding Hood," while the other half were read "Who is Afraid of Red Riding Hood?" as a second story. The researcher did not provide any mediation such as discussing illustrations, predicting story plots, or asking or answering children's questions. After the reading sessions were finished, children were allowed to manipulate the storybooks and examine the illustrations on their own.

Following each story reading session, children were asked Swindler Boutte's [28] questions individually to spark their critical discussion about the books. The four questions were related to what the children liked and did not like about each story and its protagonist, including what sounded the same and what was different across all three [26, p. 274]. After completing the three-story reading process, each child was encouraged to tell his or her own "Little Red Riding Hood" story. Their narratives were audio recorded and analyzed considering story elements such as characters, settings, plots, and themes. In addition, the children's preferences among the versions and their own points of view were examined. The first and second researchers analyzed the data independently, and the agreement between the two researchers was determined to be $98 \%$, thus providing evidence of high inter-rater reliability between the researchers [40].

\section{Findings}

\subsection{Children's Affective Responses to the Stories}

Following each book reading session, children were asked how they felt while listening to each story. The researchers did not prefer using directive questions such as "Do you like this story?" Rather, children were provided pictures of three faces (smiling, neutral, and frowning) to convey their feelings and affective responses to each story. As illustrated in Table 1, 96.67\% of children most enjoyed listening to the original version, $90 \%$ most enjoyed listening to "Very Little Red Riding Hood," and 86.66\% most enjoyed listening to "Who is Afraid of Red Riding Hood?"

Table 1. Children's feelings about the stories

\begin{tabular}{ccccc}
\hline & \multicolumn{2}{c}{ Like } & \multicolumn{2}{c}{ Dislike } \\
\hline $\begin{array}{c}\text { The Little Red Riding } \\
\text { Hood }\end{array}$ & f & $\%$ & f & $\%$ \\
\hline $\begin{array}{c}\text { Very Little Red Riding } \\
\text { Hood }\end{array}$ & 27 & 96.67 & 1 & 3.3 \\
\hline $\begin{array}{c}\text { Who is Afraid of Red } \\
\text { Riding Hood? }\end{array}$ & 26 & 86.66 & 4 & 13.33 \\
\hline
\end{tabular}

\subsection{What Children Liked and did not Like about the Two New Versions}

Table 2 indicates what the children liked and did not like about "The Little Red Riding Hood" and the two new versions. Among the children, twenty-four liked the "Very Little Red Riding Hood" story plot, eleven liked the characters, and six liked the setting. On the other hand, three children did not like the new story plot, while two liked neither the characters nor the setting.

Table 2. What the children liked and did not like about the two new versions

\begin{tabular}{lcc}
\hline & $\begin{array}{c}\text { Very Little Red Riding } \\
\text { Hood }\end{array}$ & $\begin{array}{c}\text { Who is Afraid of Red Riding } \\
\text { Hood? }\end{array}$ \\
\hline f* & $\mathrm{f}$ \\
\hline Dislike & & 3 \\
\hline Plot & 3 & 4 \\
\hline Character & 2 & 2 \\
\hline Setting & 2 & \\
\hline Like & & 18 \\
\hline Plot & 24 & 14 \\
\hline Character & 11 & 4 \\
\hline Setting & 6 &
\end{tabular}

* Some children provided answers that covered more than one category. 
With respect to "Who is Afraid of Red Riding Hood?" eighteen children liked the story plot, fourteen liked the characters, and four liked the setting. However, four children did not like the new characters, three did not like the new plot, and two did not like the new setting. Some of the children's responses included:

"I don't like the story [Very Little Red Riding Hood] because I like the hunter. Hmmm, he has an axe and he was a strong man" (Dislikes character; B7).

"I love the story [Who is Afraid of Red Riding Hood?] because the wolf cub so pretty, because I love the wolf cub" (Likes character; G11).

"I don't like the story [Who is Afraid of Red Riding Hood]. I like that the wolf eats the grandmother and Red Riding Hood. The hunter finds the wolf and overcomes it. My father told the story and it was more exciting" (Dislikes plot; B13).

"I love the story [Very Little Red Riding Hood]. They [wolf, grandmother, and Red Riding Hood) play games, eat cake, and draw pictures. They are happy." (Likes plot; G6).

\subsection{Similarities and Differences between "Very Little Red Riding Hood" and the Original Version}

In order to reveal children's intertextual connections between the stories, they were asked to compare the new versions with the original story regarding similar and different points. Table 3 illustrates the children's comparisons regarding story elements, wherein the majority of children made comparisons in terms of the stories' wolf characters. Among the children, twenty-eight firstly reported similar physical features of the wolves across the stories. The wolves are strong, large in size, and have larger eyes and mounts than do humans. In addition, sixteen children articulated that the wolf is a good character in "Very Little Red Riding Hood" as opposed to his negative portrayal in the original version.

Secondly, twenty-four children asserted that the Red Riding Hood characters in the stories have similar physical features and clothing. Thirdly, seventeen children claimed both stories possess grandmother characters as similar points, but six children articulated that, differently from the original version, the grandmother was unfriendly toward the wolf in "Very Little Red Riding Hood." Lastly, eleven children expressed the hunter character's non-existence in "Very Little Red Riding Hood." In "The Little Red Riding Hood," six children stated they enjoyed the hunter character and the plot wherein Red Riding Hood and her grandmother were rescued from the wolf.

Table 3. Children's intertextual connections between "Very Little Red Riding Hood" and the original version

\begin{tabular}{|c|c|c|c|c|}
\hline & Similar & & Dissimilar & \\
\hline & & $f$ & & $f$ \\
\hline \multirow[t]{3}{*}{ Characters } & $\begin{array}{l}\text { The wolf } \\
\text { (physical features: big, strong, etc.) }\end{array}$ & 28 & $\begin{array}{l}\text { The wolf } \\
\text { (good character) }\end{array}$ & 16 \\
\hline & $\begin{array}{l}\text { Red Riding Hood } \\
\text { (features, clothing) }\end{array}$ & 24 & $\begin{array}{l}\text { The hunter } \\
\text { (missing character) }\end{array}$ & 11 \\
\hline & Grandmother & 17 & $\begin{array}{l}\text { Grandmother } \\
\text { (behaves unfriendly toward the wolf) }\end{array}$ & 6 \\
\hline \multirow[t]{4}{*}{ Plots } & $\begin{array}{l}\text { Red Riding Hood carries cakes/food to her } \\
\text { grandmother. }\end{array}$ & 10 & $\begin{array}{l}\text { The wolf does not eat the grandmother or Red } \\
\text { Riding Hood. }\end{array}$ & 26 \\
\hline & $\begin{array}{l}\text { Red Riding Hood encounters the wolf in the } \\
\text { forest. }\end{array}$ & 8 & $\begin{array}{l}\text { The wolf plays with Red Riding Hood (e.g., they } \\
\text { draw, dance, eat, and play games) in her } \\
\text { grandmother's home. }\end{array}$ & 18 \\
\hline & $\begin{array}{l}\text { They both visit the grandmother's } \\
\text { home. }\end{array}$ & 7 & $\begin{array}{l}\text { The wolf, Red Riding Hood, and her } \\
\text { grandmother all become friends. }\end{array}$ & 15 \\
\hline & "What big ears you have" (spoken) & 4 & Red Riding Hood cries. & 7 \\
\hline \multirow[t]{2}{*}{ Settings } & Forest & 14 & Grandmother's house & 8 \\
\hline & & & Forest & 3 \\
\hline
\end{tabular}


Most children articulated dissimilar points between the three stories' plots. As shown in Table 3, twenty-six children mentioned the wolf did not eat Red Riding Hood or her grandmother in "Very Little Red Riding Hood." In addition, eighteen children indicated that the wolf played with Red Riding Hood, while fifteen asserted that the wolf became a friend of Red Riding Hood and her grandmother in this version. On the other hand, ten children expressed that Red Riding Hood carried cakes/food to her grandmother, eight mentioned Red Riding Hood and the wolf met in the forest, seven children indicated the wolf followed Red Riding Hood to her grandmother's home, and four reported similar dialogs in both stories.

Finally, the children gave responses regarding the stories' settings. Among them, fourteen expressed that both stories take place in a large forest. However, eight children claimed the grandmother's house is different in "Very Little Red Riding Hood" regarding rooms and furniture and that there are toys for Red Riding Hood in her grandmother's house. Only three children articulated that Red Riding Hood visited her grandmother's house by tracking different routes.

\subsection{Similarities and Differences between "Who is Afraid of Red Riding Hood?" and the Original Version}

Children were asked what sounded the same and what was different between the original version and "Who is
Afraid of Red Riding Hood?" with the aim of unveiling their intertextual connections between stories. As Table 4 indicates, eighteen children reported that both stories have wolf characters, yet they expressed both a wolf cub $(n=23)$ and his mother $(\mathrm{n}=12)$ in "Who is Afraid of Red Riding Hood?" as being distinctions. Furthermore, sixteen children articulated that the Red Riding Hoods in both stories possess similar features and clothing.

With respect to dissimilar story plots, nineteen children indicated that, in "Who is Afraid of Red Riding Hood?", the wolf did not eat Red Riding Hood or her grandmother, eleven expressed that the wolf was afraid of Red Riding Hood, nine stated the wolf cub obtained permission from his mother to visit the forest alone, and seven claimed the wolf cub prepared a poster to warn the hunter that wolves do not eat humans any longer; rather, they eat vegetables and are sick of being portrayed as bad characters in fairytales. On the other hand, eight children claimed the wolf cub's mother and Red Riding Hood's grandmother warn them both about the forest's dangers.

Lastly, thirteen children claimed both stories include forest-related scenes. In addition, twenty-two children indicated that they also perceived the wolf cub's home in "Who is Afraid of Red Riding Hood?" Furthermore, eight children determined the grandmother's house as being dissimilar from that in the original version. Among the children, six articulated the wolf cub's toys as being distinct from the original version, and the children expressed that they enjoyed the wolf cub's toys.

Table 4. Intertextual connections between "Who is Afraid of Red Riding Hood?" and the original version

\begin{tabular}{|c|c|c|c|c|}
\hline & Similar & & Dissimilar & \\
\hline & & $f$ & & $\mathrm{f}$ \\
\hline \multirow[t]{3}{*}{ Character } & The wolf & 18 & The wolf cub & 23 \\
\hline & $\begin{array}{l}\text { Red Riding Hood } \\
\text { (features, clothing) }\end{array}$ & 16 & The wolf's mother & 12 \\
\hline & Grandmother & 7 & The hunter & 4 \\
\hline \multirow[t]{4}{*}{ Plots } & $\begin{array}{l}\text { The wolf cub's mother and Red Riding } \\
\text { Hood's mother warn them both about the } \\
\text { forest's dangers. }\end{array}$ & 8 & $\begin{array}{l}\text { The wolf does not eat Red Riding Hood or her } \\
\text { grandmother. }\end{array}$ & 19 \\
\hline & & & The wolf is afraid of Red Riding Hood. & 11 \\
\hline & & & $\begin{array}{l}\text { The wolf cub gets permission to visit the } \\
\text { forest. }\end{array}$ & 9 \\
\hline & & & $\begin{array}{l}\text { He prepares/draws/paints a poster to warn the } \\
\text { hunter they do not eat humans; they eat } \\
\text { vegetables. }\end{array}$ & 7 \\
\hline \multirow[t]{3}{*}{ Settings } & Forest & 13 & Wolf's house & 22 \\
\hline & & & Grandmother's house & 8 \\
\hline & & & The wolf cub owns toys at home. & 6 \\
\hline
\end{tabular}




\subsection{The Children's Preferences among the Versions}

The three storybooks were read to the participating children, who were then asked about which story they liked the most. Table 5 displays children's story preferences across the three books. Among them, 43.33\% preferred "Very Little Red Riding Hood," 30\% preferred the original version, $16.67 \%$ preferred "Who is Afraid of Red Riding Hood?" and 10\% enjoyed all three versions equally.

Table 5. Children's preferences among the three stories

\begin{tabular}{lcc}
\hline & $\mathrm{f}$ & $\%$ \\
\hline Very Little Red Riding Hood & 13 & 43.33 \\
\hline The Little Red Riding Hood & 9 & 30.00 \\
\hline Who is Afraid of Red Riding Hood? & 5 & 16.67 \\
\hline All versions & 3 & 10.00 \\
\hline Total & 30 & 100 \\
\hline
\end{tabular}

\subsection{The Children's Own Stories about Red Riding Hood}

After completing the entire storybook reading process, children were encouraged to tell their own stories about Red Riding Hood. Furthermore, the children were allowed to make any possible changes regarding story plots, characters, and settings based on their preferences.

As illustrated in Table 6, 36.67\% of children told intertextual stories. The children combined characters, settings, and plots of the various versions into single stories. Figure 2a displays one child's story about the wolf cub from "Who is Afraid of Red Riding Hood?" as well as the wolf, Red Riding Hood, and her grandmother from "Very Little Red Riding Hood," all of whom enjoyed a picnic at the forest.

The wolf cub from "Who is Afraid of Red Riding Hood?" visited the protagonist from "Very Little Red Riding Hood" to join a picnic with the wolf and grandmother from the latter version.

Table 6. Children's storytelling features

\begin{tabular}{lcc}
\hline & $f$ & $\%$ \\
\hline Intertextual/eclectic & 11 & 36.67 \\
\hline The Little Red Riding Hood & 8 & 26.66 \\
\hline Very Little Red Riding Hood & 4 & 13.33 \\
\hline Who is Afraid of Red Riding Hood? & 3 & 10.00 \\
\hline Personalized/Unique Stories & 2 & 6.67 \\
\hline Did not tell a story & 2 & 6.67 \\
\hline Total & 30 & 100 \\
\hline
\end{tabular}

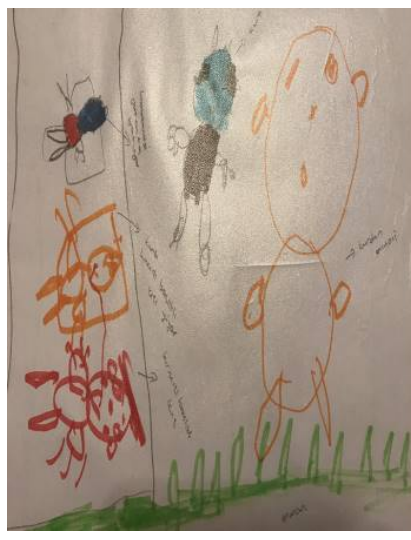

$2 \mathrm{a}$

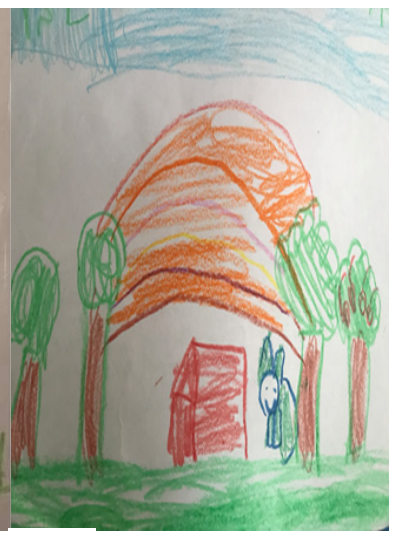

$2 b$
Figure 2. Intertextual Stories

On the other hand, half the children told replicated stories, wherein $26.66 \%$ retold "The Little Red Riding Hood," 13.33\% retold "Very Little Red Riding Hood," and $10 \%$ retold "Who is Afraid of Red Riding Hood?" Figure 3a illustrates a replicated story wherein a child focused on the dialogs between the wolf and Red Riding Hood in "The Little Red Riding Hood," claiming he simultaneously enjoyed and was nervous about the dialogs between both stories' protagonists and wolves. Figure $3 \mathrm{~b}$ depicts this child's replicated story of "Very Little Red Riding Hood," wherein the author (child) enjoyed the wolf (the green-colored character), Red Riding Hood, and her grandmother playing together.

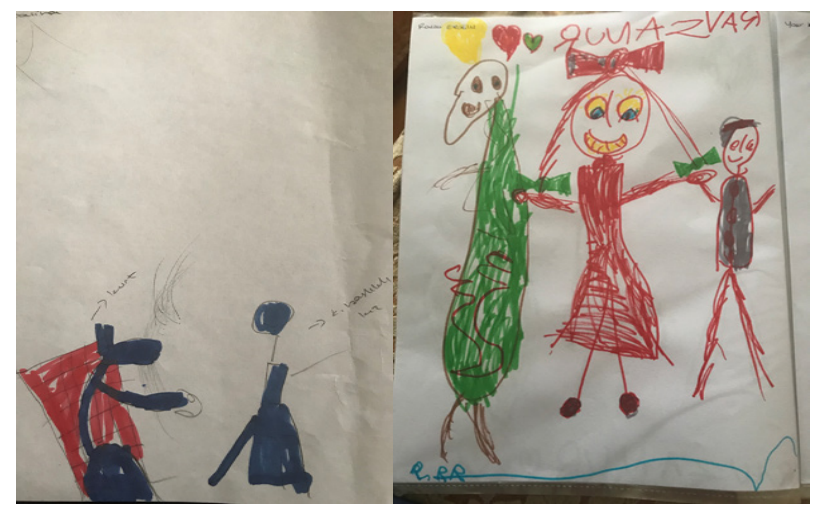

$3 a$

$3 b$

Figure 3. Replicated Stories

Furthermore, two children told more originally personalized/unique stories than others. Figure 4a depicts a little blue riding hood character taking care of the wolf's cubs when the wolf goes to work, as the wolf and the protagonist are good neighbors. Figure $4 \mathrm{~b}$ illustrates the grandmother taking the protagonist and the wolf cub to school, where they play together as classmates and where their teacher is a large wolf. Finally, two children did not tell any story. 


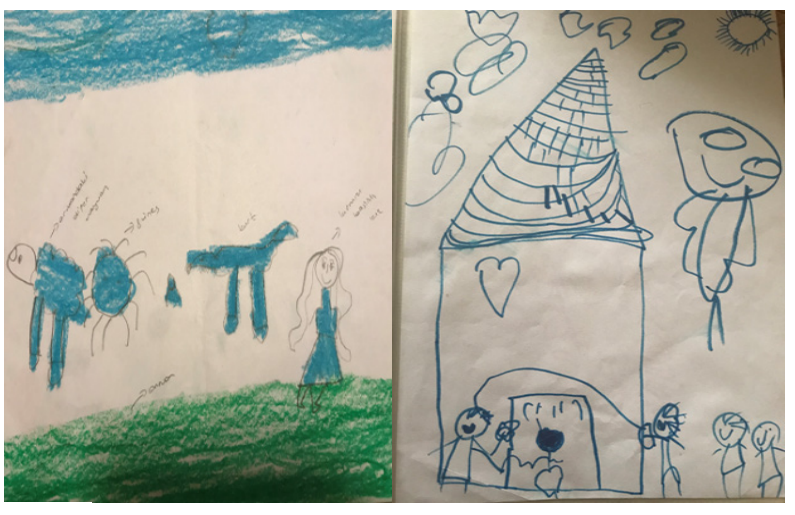

$4 \mathrm{a}$

$4 b$

Figure 4. Personalized/Unique Stories

\section{Conclusions}

Storybook reading is a widespread activity in preschool education [30,31]. However, deconstruction is an unusual method in storybook reading activities that has been suggested as a teaching method to help children with their critical meaning making. The current study presents an example of using different versions of "The Little Red Riding Hood" to deconstruct stories with preschoolers. This study's findings reveal that children enjoyed listening to the two new versions ("Very Little Red Riding Hood" [n=27] and "Who is Afraid of Red Riding Hood?" [n=26]) of the well-known story, while on the other hand, the majority of children (96.67\%) most preferred listening to the original version. Previous studies have revealed that children enjoy listening to the same story more than one time and rejoice in repetitive speaking patterns and predictable story plots [3, 29]. Porras-González [32] advocated that repetitive and predictable story patterns foster children's story comprehension. Children may engage in the story-listening process more actively and may feel more comfortable when presented with predictable story plots and dialogs. Thus, familiar stories may be more enjoyable for young children.

The study findings revealed that young children are capable of making comparisons and detecting intertextual connections between the original and new versions of "The Little Red Riding Hood". Sipe [33] found that first- and second-grade children made intertextual connections among five variants of the Rapunzel story. Although previous studies have focused on school-aged children's intertextual abilities, the present study's findings present evidence for children's abilities to compare physical features, personal features, and behaviors between characters in detail. For example, six children articulated the grandmother's behaving badly toward the wolf in "Very Little Red Riding Hood" as being distinct from the original version and subsequently expressed disapproval of this behavior. The findings also reveal that children can adopt perspectives from various characters. Studies have demonstrated that perspective-taking and theory-of-mind competencies are associated with children's story comprehension abilities [37, 41, 42, 43]. Although the study is preliminary, the findings have unearthed possible relations between young children's theory of mind and intertextual thinking. Further studies should examine young children's intertextual competencies in the scope of mind theory to elaborate our understandings of how young children process information across stories.

Similarly, the children talked about intertextual linkages between story plots wherein they focused on the climaxes as dissimilar points, such as the wolf eating neither the grandmother nor Red Riding Hood in the new versions. Children can be expected to primarily focus on a plot's main events, which include a story's most exciting and imaginative scenes. Another one of this study's interesting findings is that most children were aware that the original climax was missing in the new versions, although only three children actually sought the original climax in the new versions and thus resisted the new story plots. The children articulated that the wolf eats neither Red Riding Hood nor her grandmother, and for that reason, the new versions were not enjoyable for them. These findings convey that the majority of young children are capable of and open to making intertextual connections among stories. However, few children can exhibit story resistance. Similarly, Sipe and McGuire [34] articulated intertextual resistance, which refers to children's conflict between a well-known story and a new version. These findings, although preliminary due to a limited number of participants and previous studies mainly conducted with school-aged children, accurately portray young children's meaning-making capacities. Further studies must examine young children's intertextual reasoning across the stories in further detail.

Furthermore, the children's preferences among all versions reflect their own understandings and points of view. According to the study's findings, $43.33 \%$ of children preferred "Very Little Red Riding Hood." It is believed that developmentally appropriate adaptations in the "Very Little Red Riding Hood" plot are what captured children's attention and interest according to their responses regarding their enjoyment when the wolf, Red Riding Hood, and the grandmother played games together and became friends. And when Red Riding Hood shared her toys with the wolf; play is a crucial and fun activity for young children $[35,36]$. Similarly, $16.67 \%$ of the children who selected "Who is Afraid of Red Riding Hood?" stated they enjoyed learning about the wolf's childhood, its mother, and its toys in the story's plot and illustrations. Therefore, children's age-appropriate interests and needs may influence their story preferences.

Finally, the study findings reveal that half the children retold their stories along the same lines as those in the three versions of "The Little Red Riding Hood." On the other 
hand, eleven children drew intertextual connections in their stories and combined different characters, plots, and/or settings from the three versions. The findings provided information about preschoolers' abilities to deconstruct the meaning-making process through stories. However, the study poses limitations regarding the number of participants, the number of storybooks, and the children's unfamiliarity with using the deconstruction method with different versions of a story. This study indicates that the different versions of these stories offer children various possibilities related to the same topic, thus enabling them to think about alternative ideas and subsequently express their own. Deconstruction can be a fruitful teaching method with which early childhood teachers may encourage children to assert perspectives, think critically, and make intertextual connections among stories to foster their story comprehension abilities. Future studies should examine the deconstruction method's efficiency in children's story comprehension and story retelling skills through an experimental design that controls extraneous variables and presents clearer information in regard to causality.

\section{Acknowledgements}

The study was supported by the Kırşehir Ahi Evran University Scientific Research Projects Coordination Unit. Project No. EGT.A4.18.020. Part of this research was presented at 5th International Eurasian Educational Research Congress, 2-5 May 2018, Antalya, Turkey.

\section{REFERENCES}

[1] A. A. Zevenbergen, G. J. Whitehurst, Dialogic reading: A shared picture book reading intervention for preschoolers. In A. van Kleek, S. A. Stahl, \& E. B. Bauer (Eds.), On reading books to children: Parents and teachers, New Jersey: Lawrence Erlbaum Associates, 177-200, 2003.

[2] A. H. Hindman, C. M. Connor, A. M. Jewkes, F. J. Morrison, F. J.Untangling the effects of shared book reading: Multiple factors and their associations with preschool literacy outcomes. Early Childhood Research Quarterly, Vol. 23, No. 3, 330-350, 2008.

[3] R. Isbell, J. Sobol, L. Lindauer, A. Lowrance, The effects of storytelling and story reading on the oral language complexity and story comprehension of young children. Early Childhood Education Journal, Vol. 32, No. 3, 157-163, 2004.

[4] T. Kaefer, A. M. Pinkham, S.B. Neuman, Seeing and knowing: Attention to illustrations during storybook reading and narrative comprehension in 2 - year - olds. Infant and Child Development, Vol. 26, No. 5, 1-10, 2017.

[5] O. Korat, A. Shamir, Direct and indirect teaching: Using e-books for supporting vocabulary, word reading, and story comprehension for young children. Journal of Educational
Computing Research, Vol. 46, No. 2, 135-152, 2012.

[6] L. Van Druten-Frietman, H. Strating, E. Denessen, L. Verhoeven, Interactive Storybook-Based Intervention Effects on Kindergartners' Language Development. Journal of Early Intervention, Vol. 38, No. 4, 212-229, 2016.

[7] N. Zhou, A. Yadav, Effects of multimedia story reading and questioning on preschoolers' vocabulary learning, story comprehension and reading engagement. Educational Technology Research and Development, Vol. 65, No. 6, 1523-1545, 2017.

[8] V. Tompkins, Mothers' cognitive state talk during shared book reading and children's later false belief understanding. Cognitive Development, Vol. 36, 40-51, 2015.

[9] K. Chaemsaithong, Y. Kim, From narration to argumentation: Intertextuality in two courtroom genres. Lingua, Vol. 203, 36-50, 2018.

[10] Y. T. C. Yang, , W. C. I. Wu, Digital storytelling for enhancing student academic achievement, critical thinking, and learning motivation: A year-long experimental study. Computers\& Education, Vol. 59, No. 2, 339-352, 2012.

[11] L. R. Sipe, "Those two gingerbread boys could be brothers": How children use intertextual connections during storybook readalouds. Children's Literature in Education, Vol. 31, No. 2, 73-90, 2000.

[12] C. Wilkie-Stibbs, Intertextuality and the child reader. In P. Hunt (Ed.), International Companion Encyclopedia of Children's Literature, Vol. I, 179- 190, 2004.

[13] D. Rudd, Theorising and theories: The condition of possibility of children's literature. In P. Hunt (Ed.), International Companion Encyclopedia of Children's Literature, Vol. I, 29- 43, 2004.

[14] A. Jardine, Introduction to Julia Kristeva's" Women's Time". Signs: Journal of Women in Culture and Society, Vol. 7, No.1, 5-12, 1981.

[15] D. K. Hartman, Eight readers reading: The intertextual links of proficient readers reading multiple passages. Reading Research Quarterly, Vol. 30, No. 3, 520-561, 1995.

[16] D. Bloome, A. Egan-Robertson, The social construction of intertextuality in classroom reading and writing lessons," Reading Research Quarterly,Vol. 28, 305-323, 1993.

[17] J. Certo, Poetic language, interdiscursivity and intertextuality in fifth graders' poetry: An interpretive study. Journal of Literacy Research, Vol. 47, No. 1, 49-82, 2015.

[18] L. R. Sipe, The Construction of Literary Understanding by First and Second Graders in Response to Picture Storybook Readalouds, Columbus: The Ohio State University, 1996.

[19] M. Varelas, C. C. Pappas, Intertextuality in read-alouds of integrated science-literacy units in urban primary classrooms: Opportunities for the development of thought and language. Cognition and Instruction, Vol. 24, No.2, 211-259, 2006.

[20] J. E. Many, D. D. Anderson, The effect of grade and stance on readers' intertextual and autobiographical responses to literature, Reading Research and Instruction, Vol. 31, 60-69, 1992. 
[21] D. W. Rowe, The literate potentials of book-related dramatic play, Reading Research Quarterly, Vol. 33, No.1, 10-35, 1998.

[22] K. Kumpulainen, S. Vasama, M. Kangassalo, The intertextuality of children's explanations in a technology-enriched early years science classroom. International Journal of Educational Research, Vol. 39, No.8, 793-805, 2003.

[23] J. Torr, The pleasure of recognition: Intertextuality in the talk of preschoolers during shared reading with mothers and teachers. Early Years, Vol. 27, No.1, 77-91, 2007.

[24] D. Wolf, D. Hicks, The voices within narratives: The development of intertextuality in young children's stories. Discourse processes, Vol. 12, No. 3, 329-351, 1989.

[25] C. Elster, Importations in preschoolers' emergent readings, Journal of Reading Behaviour, Vol. 27, No.1, 65-85, 1995.

[26] G. Mac Naughton, G. William, Teaching young children: Choices in theory and practice. England: McGraw-Hill Education, 2009.

[27] J. Derrida, Dissemination. London: Continuum International Publishing Group, 2004.

[28] G. Swindler Boutte, The critical literacy process: guidelines for examining books. Childhood Education, Vol. 68, No.4, 219-224, 2002.

[29] M. Martinez, W. H. Teale, Reading in a kindergarten classroom library. The Reading Teacher, Vol. 41, No.6, $568-572,1998$.

[30] A. van Kleeck, S. A. Stahl, E. B. Bauer, Reading aloud to young children as a classroom instructional activity: Insights from research and practice. In On reading books to children . Routledge, 123-147, 2003.

[31] G. J. Whitehurst, F. L. Falco, C.F. Lonigan, J. E. Fischel, B. D. DeBaryshe, M. C. Valdez-Menchaca, M. Caulfield, M. Accelerating language development through picture book reading. Developmental Psychology, Vol. 24, No. 4, $552-559,1988$.

[32] N. I. Porras González, Teaching English through stories: A meaningful and fun way for children to learn the language. Profile Issues in Teachers Professional Development, Vol. 12, No.1, 95-106, 2010.

[33] L. R. Sipe, A palimpsest of stories: Young children's construction of intertextual links among fairytale variants. Reading Research and Instruction, Vol. 40, 333-352, 2001.

[34] L. R. Sipe, C. E. McGuire, Young children's resistance to stories. The Reading Teacher, Vol. 60, No.1, 6-13, 2006.

[35] C. Macintyre, Enhancing learning through play: A developmental perspective for early years settings. Routledge, 2016.

[36] J. L. Van Hoorn, P. Monighan-Nourot, B. Scales, K. R. Alward, Play at the center of the curriculum. Pearson, 2014.

[37] D. K. Symons, C. C. Peterson, V. Slaughter, J. Roche, E. Doyle, E. Theory of mind and mental state discourse during book reading and story - telling tasks. British Journal of Developmental Psychology, Vol. 23, No. 1, 81-102. 2005.
[38] S. F. John, M. Lui, R. Tannock, Children's story retelling and comprehension using a new narrative resource. Canadian Journal of School Psychology, Vol. 18, No. 1-2, 91-113, 2003.

[39] I. E. Boerma, S. E. Mol, J. Jolles. Reading pictures for story comprehension requires mental imagery skills. Frontiers in Psychology, Vol. 7, 2016. doi: 10.3389/fpsyg.2016.01630

[40] J. R. Hayes, J. A. Hatch, Issues in measuring reliability: correlations versus percentage of agreement. Written Communication, Vol.16, No. 3, 354-367, 1999.

[41] B. Sarı, D. Altun. Okul Öncesi Dönem Çocuklarının Hikâye Anlama ile Zihin Kuramı Becerileri Arasındaki İlișkinin Incelenmesi [An Examination of the Relationship between Preschoolers' Story Comprehension and Theory of Mind Skills]. Ana Dili Eğitimi Dergisi [Journal of Mother Tongue Education], Vol. 6, No. 4, 945-960, 2018.

[42] Y. Mano, T. Harada, M. Sugiura, D. T. Saito, N. Sadato, Perspective-taking as part of narrative comprehension: a functional MRI study. Neuropsychologia, Vol. 47, No. 3, 813-824, 2009.

[43] Y. S. G. Kim, Direct and mediated effects of language and cognitive skills on comprehension of oral narrative texts (listening comprehension) for children. Journal of Experimental Child Psychology, Vol. 141, 101-120, 2016.

\section{Children's Literature Cited}

H. Teresa, Kırmızı başlıklı küçük kız [Very little red riding hood]. Ankara: Binbir Çiçek Kitapları, 2016.

S. Davidson, Kırmızı başlıklı kız [Little red riding hood]. Ankara: Binbir Çiçek Kitapları, 2017.

S. Sahinkanat, Kim korkar kırmızı başlıklı kız'dan? [Who is afraid of red riding hood?]. Ankara: Yap1 Kredi Yayınları, 2016. 